\title{
The Local Government Strategy in Sub-District Development as the Center of Economic Development with One Sub-District One Product Based at Mukomuko Region in Bengkulu Province
}

\author{
Muhammad Fadly \\ Government Institute of Home Affairs, Indonesia
}

Tjahya Supriatna

Government Institute of Home Affairs, Indonesia

Deti Mulyati

Government Institute of Home Affairs, Indonesia

Fernandes Simangunsong

Government Institute of Home Affairs, Indonesia

Received: Aug. 23, $2018 \quad$ Accepted: Sep. 11, 2018 Online published: Sep. 28, 2018

doi:10.5296/jpag.v8i3.13545 URL: https://doi.org/10.5296/jpag.v8i3.13545

\begin{abstract}
The focus of the study was to analize the strategy of developing district as the centre of economic growth with One District One Product principle by formulating the accurate strategy in planning the development of district with One District One Product principle in Mukomuko District of Bengkulu. The existing unbalanced development and regional gap made the study important. The method used in the study was descriptive qualitative and explorative within 15 districts of Mukomuko, Bengkulu. Data collecting was done by interview, observation, documentation, triangulation (Forum Groups Discussion), and using quantitative analysis measurement (scalogram, LQ, MRP, Overlay, and interaction).

The result of the study showed 5 (five) districts as economic growth and regional
\end{abstract}


development in Mukomuko District of Bengkulu, namely: (1) District of Mukomuko City, (2) District of Lubuk Pinang, (3) District of Penarik, (4) District of Pondok Suguh, and (5) District of Ipuh. Featured products of each sub-district determined by the potential of natural resources and Gross Domestic Regional Product as featured commodities of One District One Product were: rice commodity, cattle, chicken, rubber, salt-water fish, Kelong shrimp, Soka crab, galian c (quarry), Mingkih fish, tofu/tempe, and Pandan Wangi Beach tourism. Competitive Strategy and ASOCA Analysis were used to formulate the strategy to develop district as economic growth centre.

Keywords: strategy, regional government, district development, economic growth, and one district one product.

\section{Introduction}

Good governance is a basic capital needed by the state to support the success of governance. Along with the establishment of the village as an autonomous region based on Law Number 6 of 2014 article 1 paragraph 1, the dynamics of the hierarchical relationship of local government is far more complex, where the function of the district acts as a catalyst between the district government and the village. District in accordance with the mandate of Law Number 23 Year 2014 concerning Regional Government article 209 paragraph (3) is a district/city regional apparatus that has a coordinative and functional working relationship. The role of the future district, especially in supporting the government's political will to make the village as a base for development is very heavy, then the role of a Sub-District Head in addition to carrying out his duties as a regional apparatus in accordance with the provisions of the Law must also be able to carry out the delegation of authority from the Regent as the Regional Head.

The starting point for the successful implementation of governance, development, and society towards the creation of a just prosperous and prosperous society is an increase in economic growth. If the basis of development is the village, the district acts as an "intermediate" government which is expected to be a catalyst for economic growth.

Economic growth is a very important indicator to know and evaluate the results of development carried out by a region, especially in the economic field. One of the targets of the overall national development plan in all fields and covering all economic sectors, this is in line with the current economic policy packages issued by the government. Economic growth that is followed by an increase in community welfare and a reduction in unemployment can be achieved if all components of society that seek in various sectors synergize and work hard.

In order to achieve these targets, it is necessary to analyze the development that has been achieved so far. Economic indicator monitoring activities are an effort to implement the development monitoring and control function which is a systematic planning and analysis in the development of regional development programs to be more focused and sustainable, this is also in line with world programs The United Nations, namely the Sustainable Development Goals (SDGs), means that sustainable development fulfills all aspects of demand, such as: poverty alleviation, healthy and prosperous life, quality education and decent work and 
economic growth.

Economic development can basically be interpreted as a process in which real Gross Domestic Product (GDP) or real per capita income of the population increases continuously through increasing per capita productivity. In other words, the increase in PDRB is measured in a certain period of time.

According to Masykur Wiratmo (1992) argues that economic development is more qualitative, not only increase in production, but also changes in the structure of the economy, while economic growth is more quantitative, namely the increase in income standards and the level of production output produced. Economic growth which is often expressed by increasing output and real per capita income is indeed not the only policy target in developing countries including in Indonesia. However, economic policy in raising the output growth rate needs to be done because, among others as follows:

1. Economic growth is seen as a necessary condition for improvement in improving people's welfare;

2. Economic growth is seen as a prerequisite for achieving other development goals such as the provision of infrastructure facilities and social infrastructure that are more adequate and on target.

In the process of achieving economic growth, it takes funding resources in the form of development capital, with the ability between countries or regions to provide development capital that is not the same, causing development to be achieved between countries or between regions to become disparities.

Based on Nawacita, specifically the third and seventh points, the Government is obliged to strengthen the periphery in the framework of a unitary state and realize economic independence by implementing domestic economic strategies. Greater authority is given to regions in the current era of autonomy, local governments and their communities must jointly take regional development initiatives and by using resources (ex: SDM, SDA, SDB, and SDL) so as to assess the potential of owned to be used in the preparation of the economic development model that is most suitable for the region. One that has been running is the implementation of the PATEN service program through the Ministry of Home Affairs Decree Number 04 of 2010 concerning PATEN.

The difference in regional conditions implies that the pattern of development applied by each region is different. The process of imitating the pattern of policies that have been applied and succeeded in an area, does not necessarily provide the same benefits for other regions, so that the policies taken must be in accordance with good conditions that matter the needs and potential of the region in question.

In accordance with what was conveyed by Abraham H. Maslow (1984) who argued that there are several factors that influence the economic growth of a region, among others; (1) factors of human resources, (2) factors of natural resources, (3) factors of science and technology, (4) cultural factors, and (5) factors of capital resources. 
Regional economic development is a process in which local governments and communities are able to manage existing resources and establish a partnership pattern (collaborative) between local governments and the private sector to create new jobs (new entrepreneurs) in stimulating the development of economic growth in the region. Every regional economic development effort always has the main objective to increase the number and type of employment opportunities for the community.

Efforts to achieve regional independence and equitable growth in all regions in reality are also influenced by many factors that are intertwined, related and overlapping so that regional development goals are often not achieved. In the end, there will be more advanced areas compared to other regions, even leading to economic inequality between regional residents who are in more developed regions than those in other less developed regions.

The role of local government in regional development is as follows: (1) entrepreneur/developer, namely the regional government is responsible for answering a business venture; (2) coordinator, namely the regional government can act as a coordinator in determining a policy or proposing strategies for regional development; (3) facilitator, namely the regional government can accelerate development through improvement of the attitudinal environment (behavior or culture of the community) in its area; (4) stimulators, namely the regional government can stimulate the creation and development of businesses through special actions that will affect companies to enter the area and maintain and develop companies that already exist in their regions. Because according to Supriatna (1997) that governance and development are likened to 2 (two) sides of a coin that cannot be separated, both have very close links.

The Mukomuko Region that we love, is the newly created Autonomous Region (DOB) based on Law Number 3 of 2003, a number of achievements and achievements have been achieved along with the opening of accessibility and adequate infrastructure. If we talk about 3 (three) Pillars of Development, namely: the field of education, health and people's economy. The health sector may be more prominent because it is supported by the presence of Mukomuko Hospital which has specialist medical service standards, of course we appreciate the executive and legislative commitments in supporting health care programs for the community. For the education sector also not less advanced, many apparatus human resources were given assignments to improve their competence through training and advanced studies. Hopefully this consistency will persist and be further enhanced so that what became the 2005-2025 Mukomuko District Long-Term Vision and Mission, namely: "The Realization of the Strong, Competitive and Prosperous Mukomuko Region Community" can be realized immediately.

Based on this description, the formulation of the problem raised is that the sub-districts that have not been identified can be developed as centers for economic growth based on One District One Product. The formulations of the problem that became the focus of this research are as follows:

1. How does the Regional Government develop the district as economic growth center based on One District One Product at Mukomuko Region in Bengkulu Province? 
2. Why does the Regional Government need to develop the district as economic growth center based on One District One Product at Mukomuko Region in Bengkulu Province?

3. What strategy is used by the Regional Government in developing the district as economic growth center based on One District One Product at Mukomuko Region in Bengkulu Province?

\section{Theory}

Various theories used in this study include those from the Grand Theory of Strategy and Government. Furthermore, the Middle Range Theory is discussed in the Development, Regional Development, Organizational Development in Mukomuko Regency Government, while the Application Theory focuses on economic growth and One District One Product strategy. The scientific aspect of government according to C.F. Strong (1960: 6) states that government or governance is an organization in which the right to exercise sovereign or highest power is placed. Furthermore, Strong said that the government had legislative power, executive power and judicial power. According to Franklin D. Roosevelt, the functions of government that are carried out at certain times will describe the quality of the government itself. If the government can carry out the functions of government well, then the next main task is how the service function can produce justice, the empowerment function can produce independence, and the function of development can create prosperity. Therefore, along with the results of development and empowerment carried out by the government, as well as the limitations of the government, the community is slowly required to independently meet their needs. According to Ryaas Rasyid (1999) states that governance implies regulating, managing, and governing in administering government affairs for the benefit of the people, whereas according to Taliziduhu Ndraha (2003:7) the function of development is also an integral part of service to the community. The development itself is carried out in a special way, so that public services that are experienced, felt or enjoyed by consumers, are affordable as cheaply and easily as possible when needed. The empowerment function of the government is what is done with the aim of humanizing human beings. Providing space for people to express their aspirations and use government products in the form of services. The service function that is intended is government services that cover two sides, namely civil service and public services. Civil services include recognition of human rights, respect for humanity, protection and salvation of the human soul and property, and the application of human values. According to Michael E. Potter in his book "Competitive Strategy (1980)" states that strategy is unique and its position is valuable, involving a different set of activities. When we have given or offered things in a way that is different from what we have done before. The working hypothesis/preposition in this study is the Strategy of the Regional Government in the Development of Districts as the Center for Economic Growth Based on One District and One Product in Mukomuko Regency Bengkulu Province considers the elements of Strength and Weakness of District Organizations, Embracing Values (the values adopted) by the apparatus, Broader People Hopes (broad community expectations), and Opportunity and Threats (Opportunities and Challenges) owned by the Regional Government. The framework of thought compiled in this study is described as follows: 


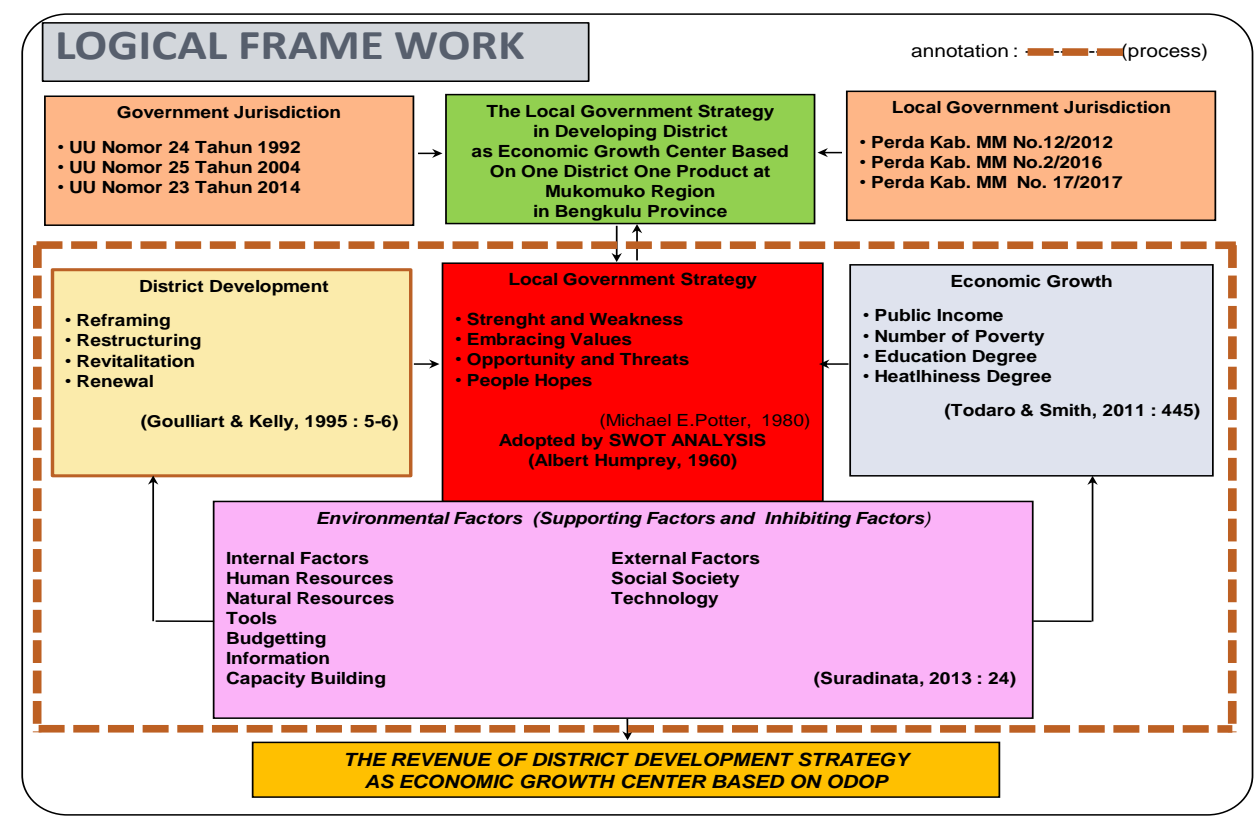

Organizational Development Theory put forward by Francis Gouillart and James N. Kelly (1995: 6-7) who suggested that there were 4 (four) elements of the framework in changing/developing an organization namely: (1) reframing, (2) restructuring, (3) revitalization, and (4) renewal. The four elements will be realized by the writer into a sub indicator as a unified strategy in realizing One District One Product atMukomuko Region in Bengkulu Province.

Growth Theory which was introduced by the French Economist Perroux (1950). The basic idea of the concept of the point of growth is that economic activity in an area tends to be blended around a small number of central points. Interaction Theory proposed by Rondinelli (1985), who interpreted that the distribution of space from the population can be regarded as organized into a central system of hierarchy and has functional links. Economic Base Theory, essentially this theory distinguishes base sector activity and non-base sector activity. Base sector activity is the growth of the sector determines the overall development of the area, while the non-base sector is the secondary sector (city following) which means that it depends on the developments that occur from comprehensive development. Development of One District One Product District through the selection of economic products in terms of the superior product sector (PDRB). This study uses qualitative research methods with a descriptive approach (describing the situation) and explorative. Determination of informants using purposive sampling and snowball techniques. Data collection techniques are carried out through interviews, field observations, documentation studies, and focus group discussions. The main instruments in the study were the researchers themselves (human instruments) and research aids using notebooks, recorders, cameras. The steps of data analysis techniques, data are collected, processed and analyzed descriptively (data display, data reduction, and conclusion: verifying). Presentation of data results is carried out informally (in narrative form) and formal (in table form). Data analysis method uses the concept of Competitive Strategy (Porter) with supporting analysis tools namely ASOCA analysis model and quantitative 
measuring tools using interaction analysis, scalogram analysis, MRP analysis, and overlay analysis. The research location includes a number of 15 (fifteen) districts in Mukomuko Regency, Bengkulu Province. The research informants amounted to 38 people consisting of stakeholders and heads of OPD in Mukomuko Region Government, 5 (five) key informants namely; (1) Regent, (2) DPRD Member, (3) Head of Bappelitbang, (4) District Heads, and (5) Chairperson of the Village Head Forum.

\section{Method}

The research method used in this study is qualitative research using descriptive analysis with explanatory research design that can provide a geographical description and distribution of each sub-district potency of resources which is calculated through a quantitative supporting approach, the type is qualitative governance method with descriptive analysis design. According to Simangunsong (2016:7) qualitative government research design forms are possible with many variations according to natural forms that are emergent based on the phenomena that arise during the research process in the field. And then, refers to Creswell (2017:266) in qualitative method the instrument of the researcher is the observer himself as the human instrument, so no need to collect random sampling of the participant such us the quantitative method. In this study the data used are primary data and secondary data. Primary data is obtained through interviews and field research, while secondary dat is obtained by studying publications that published by relevant institution. The data can be in the form of PDRB Development of each district, economic facilities, socio-political facilities, and population, the distance between sub-districts in the Mukomuko Regency Area, in Bengkulu Province that shows interaction each othes.

Collecting data is doing by noted the secondary data in each sub-district. Primary data is collected from the interview result with the informan that represented 38 informan by using purposive sampling and snow ball. Validity data is using triangulation technique (check, recheck, and crosscheck). Data collected, treated, and analyzed by using informal ways in narrative and also formal ways in picture and table.

\section{Result and Discussion}

Speaking that the pace of regional development is not only related to regulation, it also requires stability so that acceleration of development can be maximized, of course in building it needs a situation that is peaceful, safe and controlled. Stability should be felt at the village/kelurahan level, sub-district level, district/city level, provincial level, up to the state level. We need a proactive action from all elements of society towards government. As an anti-thesis of the development of the people's economy, the starting point of this theme, the authors offer the development of sub-districts as the center of economic growth based on One District One Product as an alternative solution and breakthrough Regional Government Strategy can be a formulation of strategic planning in accelerating development and accelerating/performance of government. Through participatory planning (bottom-up) based on the National Nawacita program, the potential and assets of each sub-district can be inventoried and developed based on measures of existing PDRB statistics. For example: the agricultural sector which plays an important role in the economy continues to be maintained, 
then sought other sectors as supporting sectors such as the fisheries sector and the tourism sector as well as the UMKM sector which the authors feel is promising to develop. Subdistrict clustering can be done to maximize growth points, so as to create a Center for Growth and Development in each district. The role of OPD as an accelerator is also very needed to synergize the regional programs. Sub-district Development is carried out through 2 (two) aspects, namely: the development of district organizations and district development. From the point of view of district organizational development there are 4 (four) indicators that are considered, including: (1) Reframing (2) Restructuring (3) Revitalization and (4) Renewal. From the point of view of district territorial development there are 2 (two) indicators to be considered, including: (1) regional development through an empowerment approach and (2) regional development through a local participation approach.

The reason for the importance of economic growth according to Sadono Sukirno (2016) is reviewed from various aspects, including: (1) Judging from the indicators of economic growth, including: population income, poverty rates, education degrees and health degrees and (2) Judging from the growth sector indicators economy, including: basic economic sectors and non-base economic sectors. Economic Growth Analysis in Mukomuko Region is carried out through 3 (three) analytical approaches, namely: (1) growth points, (2) growth poles, and (3) central growth. ODOP Development (One District One Product) was inspired by OVOP (One Village One Product) adopting the OTOP program (One District One Tambon) from Thailand that focusing on the development of local products in certain spatial areas can give advantages to these local products, in this case District due limitations of Human Resources (HR), Facilities and Infrastructure so that the development of the Upstream Industry in the District will be useful for building superior commodities that are ready to compete in national and global markets.

If you look at the secondary data from the MukomukoRegionPDRB sector, it still relies on the agricultural sector, in this case the plantation sub-sector with the main commodity of palm oil is worth $45.52 \%$ in 2016, followed by the dominant trade sector of $15.40 \%$ in 2016 and the sector the dominant processing industry is $12.02 \%$. The PDRB statistics show that there are no other alternatives to support the agricultural sector, especially the oil palm plantation sector, this is very crucial to think about given the slumping oil palm fruit prices on the market due to the European parliament's decision as a CPO supplier who argues that palm oil is bio diesel raw materials have an impact on environmental ecology. In this regard, the authors offer a local level development strategy program that optimizes the potential of natural resources, human resources, SDB and SDL owned by each sub-district in Mukomuko District based on identification of PDRB secondary data and interviews with informants. Identification of Featured Products Each Zoning area is based on 5 (five) sub-district growth poles with each having a hinterland area based on the distance and population in the district. The following excellent products based on ODOP sub-districts are described in Figure 4.1 below: 


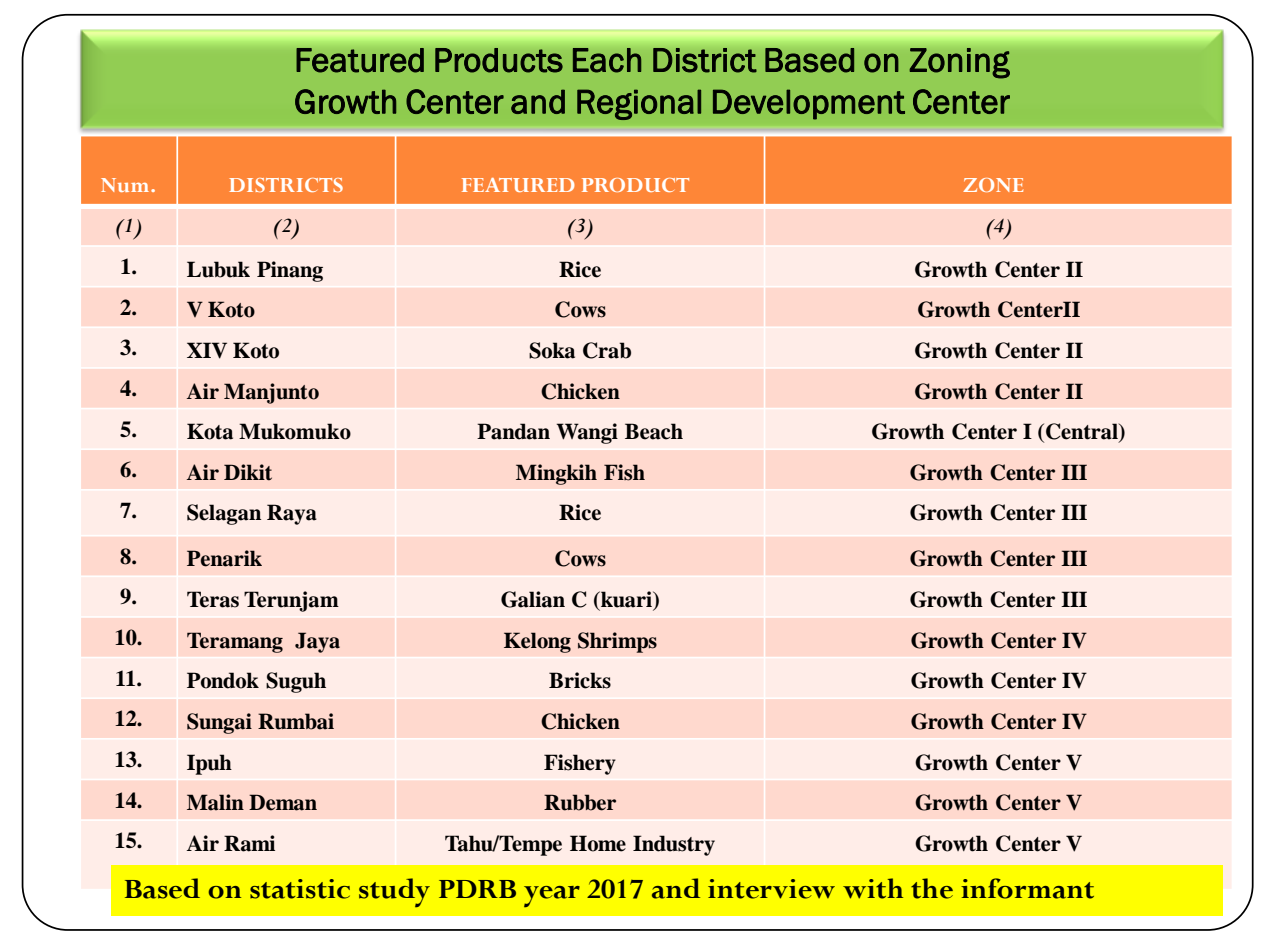

The results of the analysis carried out through a statistical calculation approach (simple quantitative) with a scalogram analysis tool, interaction analysis, Location Qoutient (LQ) analysis, MRPs analysis, Overlay analysis obtained the overall accumulation of scalogram values based on the availability of economic facilities, social facilities and government facilities in each district is based on a large 5 (five) rating district, including: (1) Mukomuko City $\{3920\}$, (2) Ipuh $\{2235\}$, (3) Penarik $\{1445\}$, (4) Lubuk Pinang $\{1335\}$ and (5) PondokSuguh $\{875\}$. Based on Figure 3.2 below:

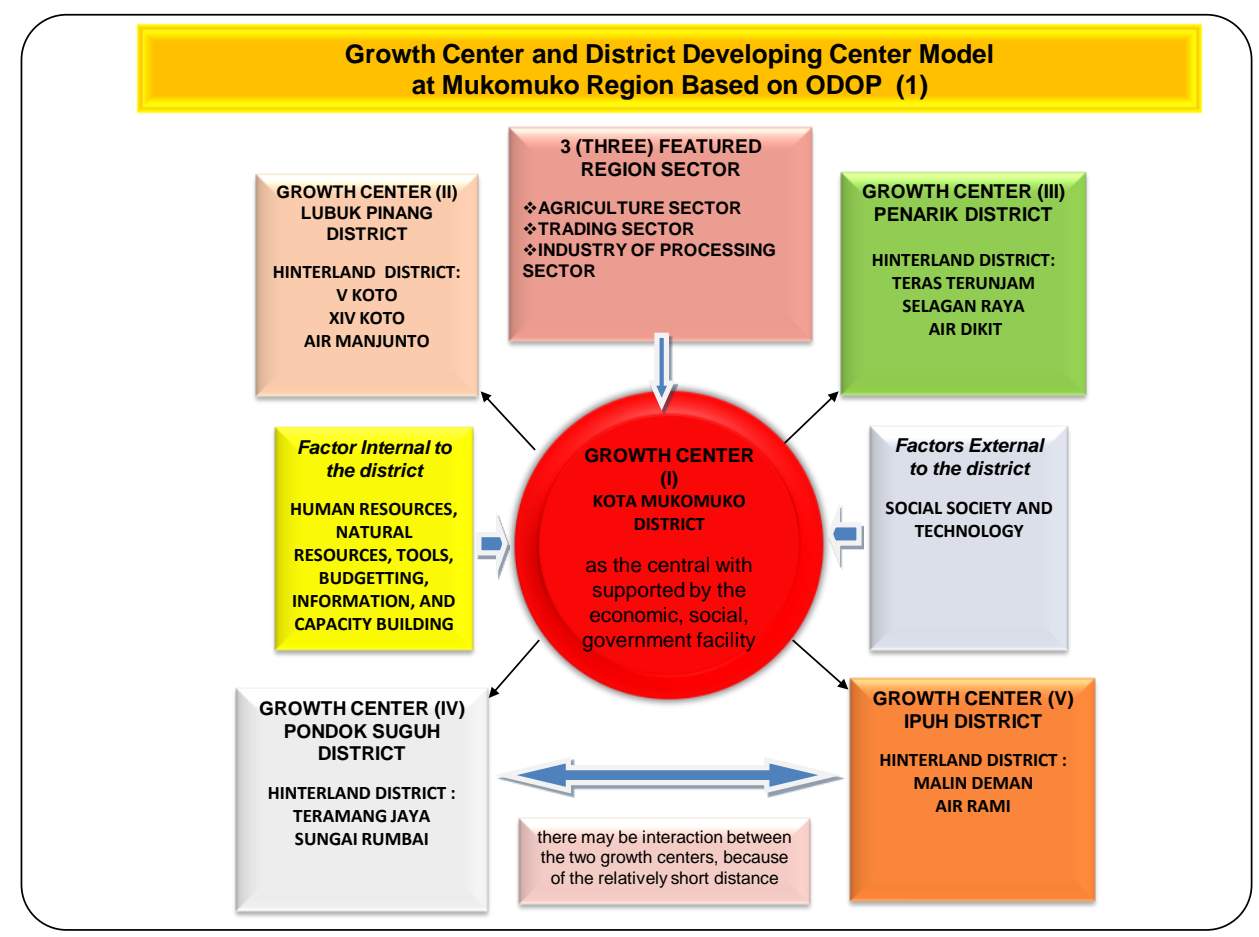


In the author's view, regional development trips are still dominated by strategies that place rural development in a separate position from urban development. Both from the development plans that are prepared and from the forms of implementation that are implemented, local governments appear to be inspired and guided by the notion that rural development has characteristics, regulations, developments and changes that are different from urban development. Whereas in fact, in the context of rural development, there are interrelated relations with urban areas, for example in meeting basic needs (food). The ODOP-Based Local Subdistrict Identification Development Strategy in Mukomuko is shown in Figure 4.3 below:

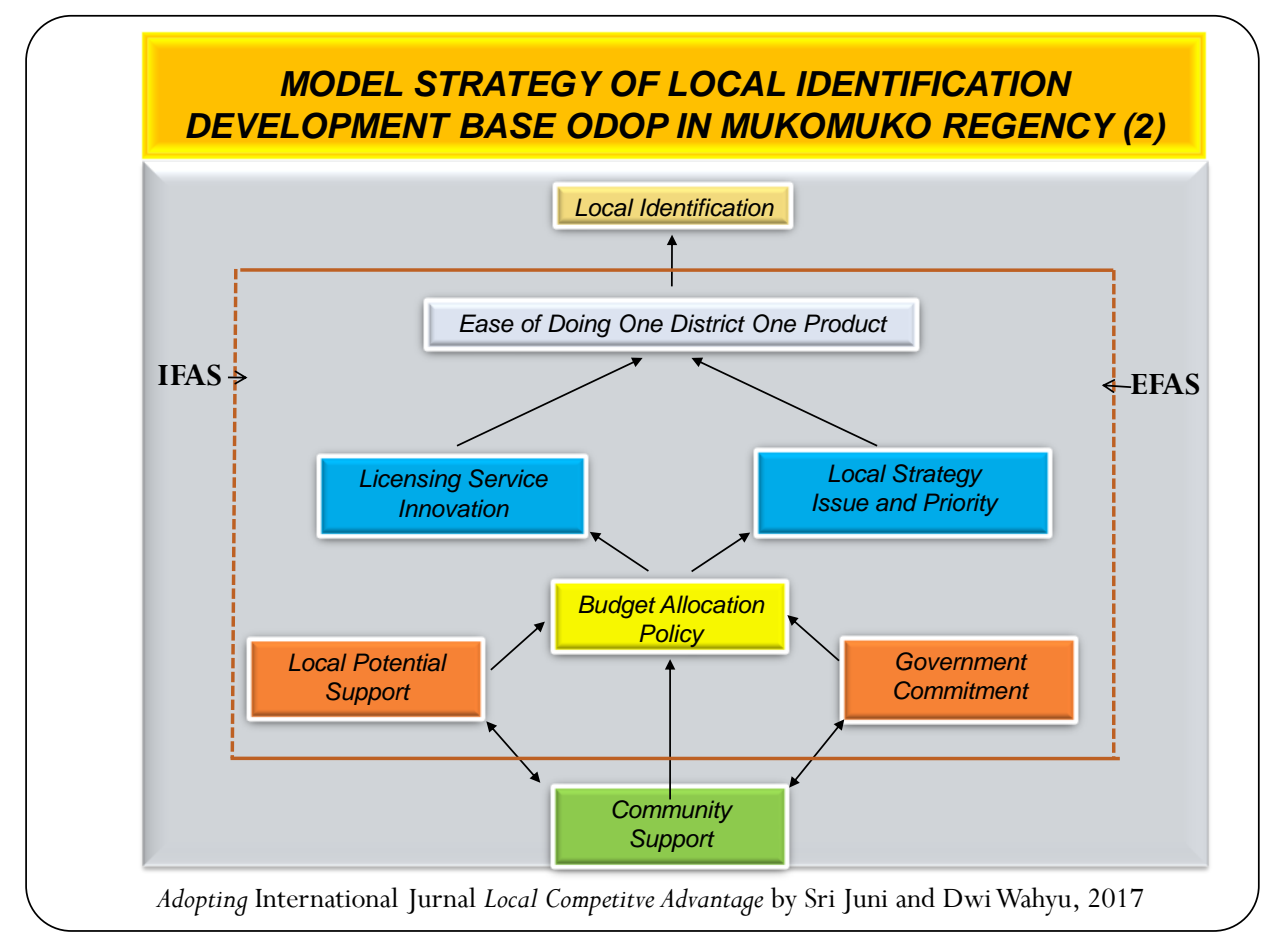

Based on the picture above, the theoretical implications generated from this study looked at the local identification strategy as an initial step in the development districts based on ODOP as the most fundamental strategy before establishing a competitive strategy, namely by putting community support in this regard, participation and empowerment as the basic foundation of ease in realize sub-district local economic productivity. ODOPin Mukomuko Region can become more competitive at the regional level of Bengkulu Province and national scale can be seen as a strategy that will increase economic growth and in turn improve the welfare of the community. Therefore, the local government must make it a priority by making a big plan for local development through the One District One Product policy. The role of potential based and local resources in planning. Therefore, it is important to improve local development. With accurate planning, the direction of regional development will be more focused. This research put in place the right identification strategy as an effort to improve local competitiveness, especially the competitiveness of districts and Mukomuko Region.

The strategy is realized by knowing the inhibiting factors and supporting factors of the implementation plan based on the analysis of internal and external environmental factors 


\section{Macrothink}

above, it can be formulated supporting factors and inhibiting factors integrated through decision making analysis (ASOCA) plays an important role in realizing the district development strategy as the center of economic growth based on the One District One Product presented in table 4.1 below:

Table 4.1. Supporting Factors and Inhibiting Factors in Developing District as the Economic Growth Center Based on ODOP at Mukomuko Region

\begin{tabular}{|c|c|c|c|c|}
\hline Num. & $\begin{array}{l}\text { Environmental } \\
\text { factor } \\
\text { (2) }\end{array}$ & $\begin{array}{l}\text { Supporting } \\
\text { Factors } \\
\text { (3) }\end{array}$ & Inhibiting Factors & $\begin{array}{l}\text { How to overcome } \\
\text { Inhibiting Factors } \\
\text { (5) }\end{array}$ \\
\hline 1. & $\begin{array}{l}\text { Human } \\
\text { Resources }\end{array}$ & $\begin{array}{l}\text { Mukomuko Local } \\
\text { Government is } \\
\text { committed to } \\
\text { realizing competent } \\
\text { and qualified } \\
\text { human resources in } \\
\text { developing the } \\
\text { region. }\end{array}$ & $\begin{array}{l}\text { Lack of interest in } \\
\text { the apparatus, as } \\
\text { well as the } \\
\text { community in } \\
\text { developing } \\
\text { themselves and } \\
\text { skills to face global } \\
\text { competition. }\end{array}$ & $\begin{array}{l}\text { Local governments must focus on } \\
\text { strengthening human resources, } \\
\text { because the present economic } \\
\text { resources are no longer derived from } \\
\text { natural resources, but human beings } \\
\text { are knowledgeable, competent, and } \\
\text { skilled. }\end{array}$ \\
\hline 2. & $\begin{array}{l}\text { Natural } \\
\text { Resources }\end{array}$ & $\begin{array}{l}\text { MukomukoRegion } \\
\text { has sufficient } \\
\text { natural resource } \\
\text { potential to increase } \\
\text { local revenue }\end{array}$ & $\begin{array}{l}\text { Natural Resource } \\
\text { Management has } \\
\text { not been well } \\
\text { managed, targeted } \\
\text { and comprehensive. }\end{array}$ & $\begin{array}{l}\text { The use of natural resources } \\
\text { effectively and efficiently to meet the } \\
\text { needs of life and improve the welfare } \\
\text { of life. }\end{array}$ \\
\hline 3. & Tools & $\begin{array}{l}\text { Specifically, health } \\
\text { care facilities in } \\
\text { Mukomuko } \\
\text { Regency are quite } \\
\text { adequate because } \\
\text { they are supported } \\
\text { by B-accredited } \\
\text { hospitals and the } \\
\text { presence of } \\
\text { specialists. }\end{array}$ & $\begin{array}{l}\text { Infrastructure as a } \\
\text { support for the } \\
\text { successful } \\
\text { development in } \\
\text { Mukomuko } \\
\text { Regency is still } \\
\text { very minimal. For } \\
\text { example the } \\
\text { Farming Business } \\
\text { Road (JUT) is not } \\
\text { yet feasible. }\end{array}$ & $\begin{array}{l}\text { Improvement of facilities and } \\
\text { infrastructure and infrastructure is } \\
\text { focused on providing basic services, } \\
\text { infrastructure to support leading } \\
\text { sectors, and urban infrastructure. }\end{array}$ \\
\hline 4. & Budgetting & $\begin{array}{l}\text { Financial } \\
\text { Administration in } \\
\text { Mukomuko District } \\
\text { has taken place in } \\
\text { an orderly manner, } \\
\text { this is evidenced by } \\
\text { obtaining the title } \\
\text { of Fair without } \\
\text { Exception (WTP) }\end{array}$ & $\begin{array}{l}\text { Overall, } \\
\text { Mukomuko'sDAU } \\
\text { source was very } \\
\text { minimal as well as } \\
\text { a small source of } \\
\text { income, so the } \\
\text { development } \\
\text { process in } \\
\text { Mukomuko }\end{array}$ & $\begin{array}{l}\text { Adequate budget allocation based on } \\
\text { empirical studies and arguments that } \\
\text { are clearly certainly not an obstacle in } \\
\text { determining budget policy. } \\
\text { Performance-based budgeting } \\
\text { approaches can be applied in } \\
\text { Mukomuko District. }\end{array}$ \\
\hline
\end{tabular}


from BPK-RI in Regency was slow, 2018.

5. Information

6. Social Society

7. Technology

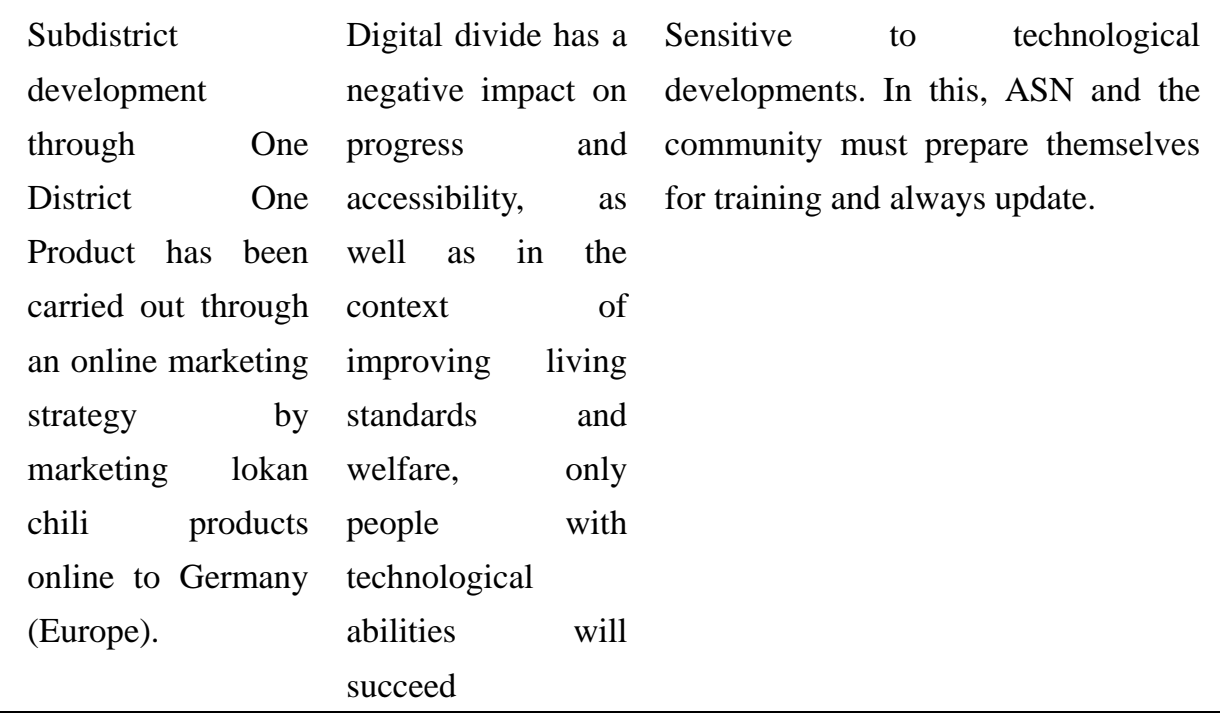

Very fast information flow is certainly very helpful in getting information in real time easily, the ability to absorb information quickly is the solution. capital, so the absorption of information tends to be faster.

as was the

Sub-District Head's budget.

network covers up Regency still needs to villages located operators who have skills in operating computer technology based on application and data services.

Gradually the The difficulty of community has the changing the mind desire to go forward set and behavior of and have a high the people in sense of curiosity, Mukomuko therefore change Regency, especially agents are needed in the indigenous providing people inspiration. (descendants) so that they tend to be quickly satisfied with their current lives.

7echnolog

Source: Mukomuko Regency, 2017

Finally, citing what was conveyed by Prof. Khasan Effendy is certain that the strategy is core and operational, the core is the involved component/stakeholder, while the operation is the political will regulation which will be applied by the Regional Head in the realization of the 
Vision Mission. Let us together build Mukomuko which we love based on ASOCA's terminology leadership analysis which was initiated by Prof. Ermaya Suradinata namely: Abillity, Strength, Opportunity, Culture, and Agillity so that any problems and challenges can be overcome and of course a religious, independent and democratic society based on Vision and the mission can be realized soon.

\section{Closing}

The development of thedistrict as the center of economic growth based on One District One Product in Mukomuko Regency must be carried out holistically and comprehensively. The reason for the importance of district development as a center for economic growth based on One District One Product in Mukomuko Regency relates to generating the potentials of each district based on the calculation of PDRB into a single unit basedon regional products so as togive effect to the acceleration of regional economic growth. The operational strategy of regional government in the development of districts as the center of economic growth based on One District One Product in Mukomuko Regency, among others: (1) Development Strategy through the development of the district area, especially to open theisolation of the region, (2) Strategy for developing the spirit and motivation of the Sub-District Head and Head of Service/Institutions to be able to cooperate; (3) Strategy through Empowering Community Institutions, (4) Strategy through submission of substance authority to the Sub-District Head, (5) Strategy through Capacity Building of Apparatus and Community, (6) Strategy for Community Economic Empowerment through enhancing empowerment and coaching in the field soft agriculture, fisheries, and micro and small businesses, (7) Strategies to improve the quality of life of rural communities and explore the superior potential of villagges and districts that can be developed in the hope of creating employment opportunities (8) Strategy through increasing community participation, (9) Strategy to increase the participation of large private companies through CSR (Cost Sharing Responsibility) programs that directly touch the needs of the respective district communities, (10) Strategy to maintain the quality of life and health of the community and a healthy lifestyle, and (11) Strategy for improving infrastructure and rural transportation in the district scope to facilitate the distribution of goods and services.

Increase synergy between sub-districts and SKPD and coordinate with the Central Statistics Agency (BPS) in Mukomuko Region in implementing programs and activities to encourage the rate of economicg rowth of sub-districts through the One District One Product approach (one district of one product). Regional economic stability is closely related to theworld of politics in a region. Therefore, regional conditions are sought in a conducive situation so that a stable economy has an impact on investment and public trust. Determination of the district development strategy as a center of economic growth through a local participation approach and community empowerment in each district through strategic planning can need to be supported by regional development policies.

To increase the capacity of the district heads, education and training should be carried out in the economic field, especially regarding the empowerment of small economic communities and the creation of new entrepreneurs in their working areas. 


\section{References}

Creswell, J. W. (2017). Reseach Design: Pendekatan Kualitatif, Kuantitatif, dan Campuran, Yogyakarta, Publisher: Pustaka Belajar.

Effendy, K. (2010). Memadukan Metode Kuantitatif Kualitatif, Bandung, Publisher: CV. Indra Prahasta.

Goulliart, F. J., \& dan Kelly, J. N. (1995). Transforming the Organization, McGraw-Hill Publishing: Minnesota, USA.

Maslow, A. H. (1984). Motivation and Personality, Free Management Library: USA.

Ndraha, T. (2002). Kybernology 1 \& 2 (Ilmu Pemerintahan Baru). Jakarta: RinekaCipta.

Porter, M. E, (1980). Competitive Strategy: Techniques for Analyzing Industries and Competitors, First Free Press Edition, New York, USA.

Rasyid, R. (1998). Makna Pemerintahan: Tinjauan Dari SegiEtika Dan Kepemimpinan. Jakarta. Yasrif Watampone.

Rodinelli, D. A. (1985). Planning Development Project. Boston: Little Brown AndCompany.

Simangunsong, F. (2015). MetodologiPenelitianPemerintahan. Bandung: IPDN Literary Book.

Strategi Pembangunan dan Kemiskinan. Jakarta: Publisher Rineka Cipta. (2002).

Strong, C. F. (1960). Modern Political Constitusional, Sidgwick and Jackson Ltd, London.

Sukirno, S. (2016). Mikro Ekonomi Teori Pengantar 31st Edition. Depok. Publisher: Raja GrafindoPersada.

Supriatna. T. (1997). Birokrasi, Pemberdayaan, dan Pengentasan Kemiskinan. Jakarta: Publisher Rineka Cipta

Suradinata, E. (2013). Analisis Kepemimpinan Studi Pengambilan Keputusan. Sumedang: Publisher Alqaprint.

Wiratmo, M. (1992). Ekonomi Pembangunan, Ikhtisar Teori, Masalah dan Kebijakan. First Edition. Yogyakarta: Publisher Media Widya Mandala.

\section{Copyright Disclaimer}

Copyright for this article is retained by the author(s), with first publication rights granted to the journal.

This is an open-access article distributed under the terms and conditions of the Creative Commons Attribution license (http://creativecommons.org/licenses/by/4.0/). 